Journal of MMIJ Vol.123 p.675 - 677(2007)

C2007 The Mining and Materials Processing Institute of Japan

\section{報告}

Technical Report

\section{三井串木野鉱山 ( 株 ) における金・銀製錬 *}

\title{
Gold and Silver Smelting at Mitsui Kushikino Mining Co., Ltd.
}

\author{
by Masayuki TANAKA ${ }^{\mathrm{a}}$
}

a. Mitsui Kushikino Mining Co., Ltd.

(Corresponding author E-mail: ma_tanaka@ksn.mitsui-kinzoku.co.jp)

Mitsui Kushikino Mining Co., Ltd. has the long history and is the only refinery in Japan which is capable of all slime cyanidation process for gold and silver ore. The Kushikino smelting plant started operation for precious metal recycling in 1978. Nowadays the recycle business has grown and the plant, so called "Hybrid smelting plant", is Smelting precious metals from gold-silver ore and recycling materials.

KEY WORDS: Gold, Silver, All Slime Cyanidation Process, Recycling Materials, Kushikino Mine

\section{1. 緒言 1,4$)$}

三井串木野鉱山（株）は，鹿児島市から東北東へ約 $40 \mathrm{~km} ，$ 東 シナ海に面した，いちき串木野市に位置する。金鉱山・金銀製錬 所としての歴史は古く, 西山, 芹ケ野, 荒川, 羽島, 等の鉱脈群 が存在した。開山時期には諸説あり, 主力の西山坑の発見は万治 年間 $(1658 \sim)$ とも鎌倉時代とも言われ，1650 年ころには探査が 行われていた記録もある。江戸時代には主に島津家によって採掘 されていた。明治に入り 1906 年に三井鉱山合名会社の経営となっ た。戦時中は一時休止し, 戦後三井金属鉱業 (株) ( 当時は神岡 鉱業 (株)) 串木野鉱業所として再スタートし, 1964 年には三井 金属鉱業 (株)の $100 \%$ 子会社として, 現在の三井串木野鉱山 (株) (以下串木野鉱山社と略) が設立された。

串木野鉱山での鉱石採掘は 1997 年に, 円高・建值の下落によ る採算悪化により中止されている。国内鉱山の通算産金量として は, 1 位の菱刈鉱山 (2006 年 7 月末現在で $\left.153 \mathrm{t}^{6)}\right), 2$ 位の佐渡, 3 位の鴻之舞 ( 北海道 ) に続いて, 国内第 4 位の約 $56 \mathrm{t}$ である。

また当社は, 薩摩半島南部の知覧町に位置する赤石 (あけし) 鉱山において含金珪酸鉱の採掘を行い, 現在も国内の銅製錬所一 熔剤原料として販売している。

一方，串木野の製錬設備は，1914 年に我が国初の全泥青化製 棟工場として操業を開始した。戦中，戦後の一時期は，金鉱業整 備令により製錬設備が撤去され操業を休止していたが，1949年 に操業を再開し, 現在でも国内で唯一全泥青化製棟法による操業 を続けている。

1978 年には市中から回収したリサイクル原料による金銀回収 がスタートし，1986 年からは買鉱製錬を開始した。1997 年の串 木野鉱山採掘中止に伴い，現在では金銀鉱石の買鉱製錬と，リ少

* 2007 年 5 月 28 日受付 10 月 11 日受理

1. 普通会員 三井串木野鉱山 ( 株) 生産部 貴金属製棟課長

[ 著者連絡先 ] FAX : 0996-32-4477

E-mail : ma tanaka@ksn.mitsui-kinzoku.co.jp

キーワード : 金, 銀, 全泥青化製棟, シアン, リサイクル, 串木野鉱山
イクルで入荷する電気電子部品，メッキ廃液等から金・銀を回収 する「ハイブリッド製錬所」となっている。

本報では，串木野鉱山社の金・銀製錬について報告する。

\section{2. 最近 10 年間の経緯}

最近 10 年間の鉱石処理量を Table 1 に示す。この期間，青化

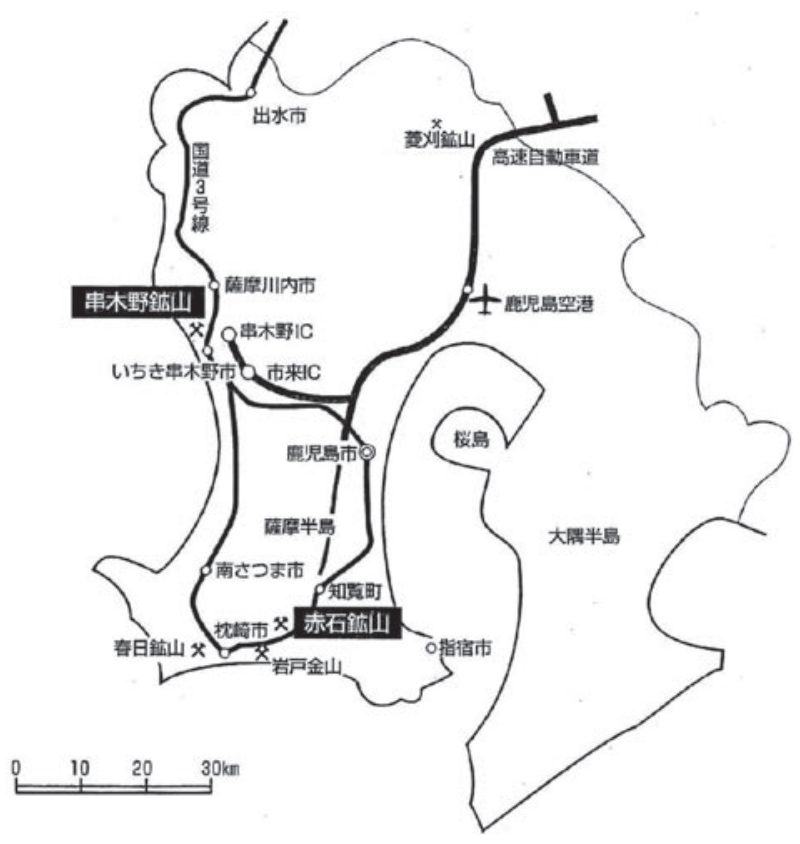

Fig.1 Location of the Kushikino mine.

Table 1 Annual quantity of treated gold ore at the Kushikino cyanidation plant.

\begin{tabular}{|c|c|c|c|c|c|c|c|c|c|c|}
\hline 年度 & 1997 & 1998 & 1999 & 2000 & 2001 & 2002 & 2003 & 2004 & 2005 & 2006 \\
\hline 鉱量 (千t) & 23.8 & 20.7 & 32.7 & 31.5 & 18.5 & 21.1 & 24.5 & 23.0 & 24.2 & 25.2 \\
\hline$\overline{A u}$ 品位 $(\mathrm{g} / \mathrm{t})$ & 7.1 & 21.7 & 23.3 & 27.8 & 22.9 & 21.5 & 22.8 & 25.7 & 21.2 & - \\
\hline
\end{tabular}


Table 2 Annual quantity of treated recycle material at the Kushikino recycling plant.

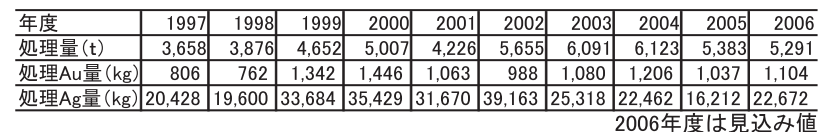

Table 3 Solubility of precious metals.

\begin{tabular}{l|c|c|c|c}
\hline & $\mathrm{Au}$ & $\mathrm{Ag}$ & $\mathrm{Cu}$ & $\mathrm{Pt}$ \\
\hline 王水 & $\bigcirc$ & $\times$ & $\bigcirc$ & $\bigcirc$ \\
\hline シアン & $\bigcirc$ & $\bigcirc$ & $\bigcirc$ & $\triangle$ \\
\hline 硝酸 & $\times$ & $\bigcirc$ & $\bigcirc$ & $\times$ \\
\hline 塩酸 & $\times$ & $\times$ & $\bigcirc$ & $\times$ \\
\hline 硫酸 & $\times$ & $\times$ & $\bigcirc$ & $\times$ \\
\hline
\end{tabular}

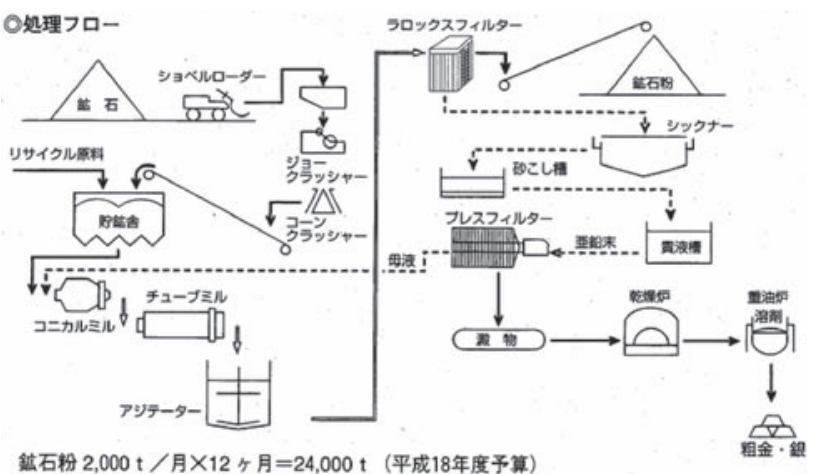

Fig.2 Flowchart of cyanidation process

製棟工程での処理鉱石量は，一時期を除いて 20 千 $\mathrm{t} \sim 24$ 千 $\mathrm{t} /$ 年 を維持している。

一方，リサイクル原料については Table 2 に示寸とおり，1997 年に約 3.7 千 $\mathrm{t}$ であった処理量は順調な伸びを見せ，一時的に落 ち込む年はあるものの, ここ数年は年間 5 千 $\mathrm{t} \sim 6$ 千 $\mathrm{t}$ で推移し ている。

\section{3. 処 理 工 程}

次に，青化製棟，リサイクルの各工程フローを紹介する。

\section{3- 1 青化製棟工程 2)}

Table 3 は各種試薬に対する金，銀，銅，白金の溶解性を簡略 化して示したものである。全泥青化製棟法においては，金・銀を 同時に溶解することができるシアンを使用するのが最大の特徴で ある。

Fig. 2 に串木野鉱山社における青化製棟工程の概略フローを示す。 また，青化製棟工程の主要設備一覧を Table 4 に示す。

鉱石および鉱石と同じ扱いが必要なガラス・セラミック原料等 はブレーキクラッシャー $(37 \mathrm{~kW} \times 2$ 台 $)$, 続いてコーンクラッ シャー (2 台) にて $-15 \mathrm{~mm}$ に破砕され, 貯鉱舎 (6 室, 800t) に貯 鉱される。

貯鉱舎から抜き出された粉砕鉱石等は，シアン液を添加しなが らコニカルミル，チューブミルの 2 段のボールミルによって湿式 磨鉱されて所定の粒度まで粉砕される。チューブミル出口粒度は 過去には - 200 メッシュであったが, 現在では脱水ケーキの水分 を下げるため, 粗めに調整している。ミルを出たスラリーはアジ テーターにて空気を吹き込みながらリーチングし，金銀を液中に 取り込む。

リーチング後のスラリーは, ラロックスフィルターによって固 液分離される。脱水工程で分離したろ夜 ( 金液) は亜鉛末置換を
Table 4 The main machine at the cyanidation plant.

\begin{tabular}{l|l|l|l|l}
\hline No & 名称 & 諸元 & 動力 $(\mathrm{kW})$ & 台数 \\
\hline 1 & ブレーキクラッシャー & $610 \times 360 \mathrm{~mm}$ & 37 & 2 \\
\hline 2 & コーンクラッシャー & $1,200 \phi$ & 75 & 2 \\
\hline 3 & $\begin{array}{l}\text { ジャイレックス・スクリ } \\
\text { ーン }\end{array}$ & $1,200 \mathrm{~W} \times 3,000 \mathrm{~L}$ & 5.6 & 2 \\
\hline 4 & 貯鉱舎 & $800 \mathrm{t}(6$ 室 $)$ & & 1 \\
\hline 5 & コニカルミル & $2,400 \phi \times 900 \mathrm{~L}$ & 131 & 2 \\
\hline 6 & 分級機 & $2,400 \times 6,000$ & 7.5 & 2 \\
\hline 7 & チューブミル & $1,800 \phi \times 4,200 \mathrm{~L}$ & 169 & 1 \\
\hline 8 & アジテーター & $8,530 \phi \times 6,700 \mathrm{H}\left(380 \mathrm{~m}^{3}\right)$ & 3.7 & 1 常用 \\
\hline 9 & ラロックスフィルター & $150 \sim 200 \mathrm{~kg} / \mathrm{m} 2 \mathrm{~h}\left(\right.$ 滤過面積 $\left.38 \mathrm{~m}^{2}\right)$ & - & 1 \\
\hline 10 & シックナー & $18,000 \phi \times 3,600 \mathrm{H}\left(950 \mathrm{~m}^{3}\right)$ & 3.7 & 1 常用 \\
\hline 11 & 砂漉槽 & $6,100 \phi \times 1,500 \mathrm{H}\left(44 \mathrm{~m}^{3}\right)$ & なし & 2 \\
\hline 12 & 貴液槽 & $6,100 \phi \times 2,400 \mathrm{H}\left(70 \mathrm{~m}^{3}\right)$ & なし & 1 \\
\hline 13 & 脱酸塔 & $1,500 \phi \times 3,660 \mathrm{H}\left(7 \mathrm{~m}^{3}\right)$ & - & 1 \\
\hline 14 & 澱物プレス & $1,680 \mathrm{~W} \times 4,550 \mathrm{~L} \times 2,278 \mathrm{H}\left(33 \mathrm{~m}^{2}\right)$ & - & 1 \\
\hline
\end{tabular}

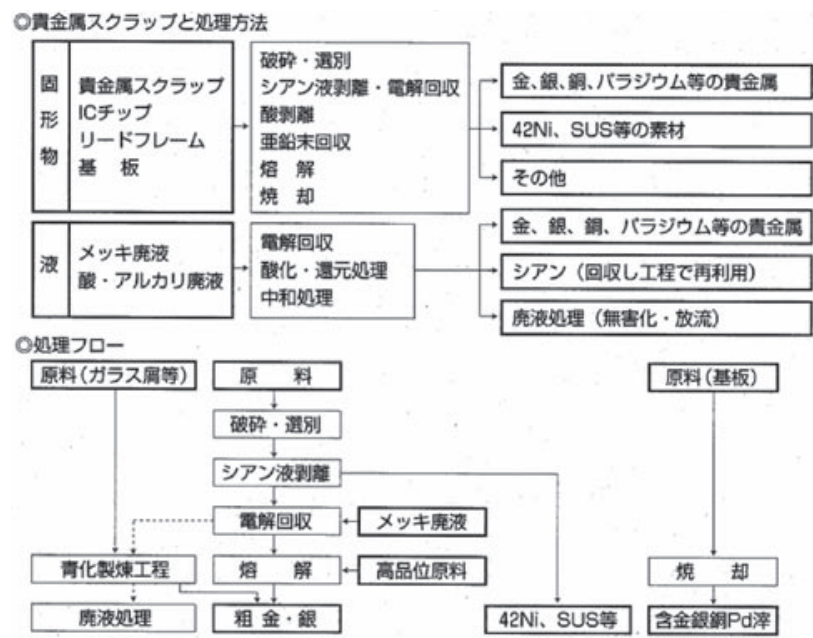

\section{責金凮スクラップの性状にあわせ処理工程を遛定}

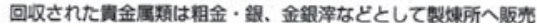

Fig.3 Recycle process diagram.

行い, 金銀の沈殿物として回収する。この際, 金液中の溶存酸素 は亜鉛末を消費させるので, あらかじめ脱酸素塔で減圧し溶存酸 素を減少させる。5)

金のシアン液への溶解，覀鉛末による置換還元反応式は，以下 に示すとおりである。

溶解: $4 \mathrm{Au}+8 \mathrm{CN}^{-}+\mathrm{O}_{2}+2 \mathrm{H}_{2} \mathrm{O}=4\left[\mathrm{Au}(\mathrm{CN})_{2}\right]^{-}+4(\mathrm{OH})^{-} \ldots$ (1)

還元 : $4\left[\mathrm{Au}(\mathrm{CN})_{2}\right]^{-}+2 \mathrm{Zn}=2\left[\mathrm{Zn}(\mathrm{CN})_{2}\right]^{-}+4 \mathrm{Au}$

一方脱水工程で分離した残渣は，含金銀珪酸粉として銅製錬所 八出荷する。

$3 \cdot 2$ リサイクルエ程 3 )

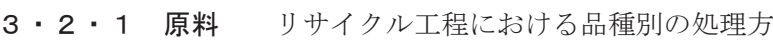
法と処理フローをFig. 3 に示す。また，主要機械設備を Table 5 に示す。集荷したリサイクル原料は，青化製棟工程で処理するも のと, リサイクル工程で単独処理するものがあり, 固形原料と液 体原料に大別される。固形原料は貴金属スクラップ, IC チップ, 液晶に代表されるガラス類, 各種リードフレームや電気電子機器 基板などである。液体原料は含金銀めっき廃液, 酸・アルカリ廃 液などである。

3・2 2 破砕前処理工程破砕による前処理が必要な原 料は，樹脂でモールドされた IC やリードフレームなどで，高速 剪断破砕機で $-15 \mathrm{~mm}$ とし, 磁選機で銅系樹脂付品と鉄・ニッケ 
Table 5 The main machines at the recycle plant.

\begin{tabular}{|c|c|c|}
\hline 主要工程名 & 設備名 & 機械、能力、その他 \\
\hline 1.破砕前処理工程 & & $\begin{array}{l}\text { 高速剪断破砕機 } \\
\text { ヘリカルクラッシャー } \\
\text { 三段ロール、磁選器 他 }\end{array}$ \\
\hline $\begin{array}{l}\text { 2アルカリ処理、 } \\
\text { 溶解工程 } \\
\text { 電解剥離工程 }\end{array}$ & $\begin{array}{l}\text { 回転笔式溶解設備 } \\
\text { バレル式溶解設備 } \\
\text { ミキサー型溶解装置 } \\
\text { サンプリング設備 } \\
\text { サン゙電解剥離設備 }\end{array}$ & $\begin{array}{l}1.5 \mathrm{~m}^{3} \times 2 \text { 槽 } \quad 9.0 \mathrm{~m}^{3} \times 4 \text { 槽 } \\
1,000 \mathrm{~kg} \text { /回 } \\
50 \sim 1,000 \mathrm{k} \mathrm{g} \text { /回 } \quad 4 \text { 台 } \\
\text { 貯液槽、万過槽、計量器、秤量器 } \\
3.6 \mathrm{~m}^{3} \times 18 \text { 槽 } \\
\text { 整流器 } 15 \mathrm{~V} \times 2,000 \mathrm{~A} \quad 7 \text { 台 }\end{array}$ \\
\hline 3.酸処理溶解工程 & & $2 \mathrm{~m}^{3} \times 1$ 槽 加圧脱水機 他 \\
\hline 4.金銀電解回収工程 & $\begin{array}{l}\text { 電解回収設備 } \\
\text { 化学還元処理設備 }\end{array}$ & $\begin{array}{l}\text { Au } 5 \mathrm{~m}^{3} \times 5 \text { 槽 } \quad \text { Ag } 5 \mathrm{~m}^{3} \times 4 \text { 槽 } \\
\text { 整流器 } 15 \mathrm{~V} \times 1,000 \mathrm{~A} \quad 5 \text { 台 } \\
\text { 整流器 } 15 \mathrm{~V} \times 500 \mathrm{~A} \quad 4 \text { 台 } \\
\text { 反応槽、万過槽 }\end{array}$ \\
\hline 5.焼却工程 & 乾留ガス化炉 & $\begin{array}{l}15 \mathrm{~m}^{3} \times 2 \text { 基 (バッチ式) } \\
\text { 排ガス処理設備一式、燃焼塔、冷却 } \\
\text { 炉、冷却塔、バグフィルター、誘引 } \\
\text { ファン } 75 \mathrm{~N} \mathrm{~m} \mathrm{~m}^{3} / \mathrm{min} \text { 、消石灰・活性炭 } \\
\text { 供給装置 他 }\end{array}$ \\
\hline
\end{tabular}

ル系素材を選別する。さらにそれぞれの原料は必要に応じて三段 ロール破砕機で二次破砕を行い，樹脂と分離する。

$3 \cdot 2 \cdot 3$ 金銀剥離工程 金・銀が表面に出ている原料は, シアン液によって金・銀を剥離溶解する。適用する溶解設備は原 料の性状, 形状によって異なり, 以下の 4 種類の設備を使い分け ている。

(1) 回転篭式溶解設備

(2) ミキサー式溶解設備

(3) バレル式溶解設備

(4) エアレーション溶解設備

$3 \cdot 2 \cdot 4$ 金銀電解回収工程 メッキ工場から排出される シアン含有の金銀廃液は, 金液, 銀液に分けるか, 金銀混合のま ま電解回収する。前述の金銀剥離工程で溶解した金銀液も，この 工程で電解回収する。貴金属を回収した後の電解廃液は青化製棟 工程へ送られる。洗浄液やろ過液といった低濃度のシアン液は, 廃液処理工場へ送り無害化したあと工場外へ排出する。

3·2・5 アルカリ電解工程主にメッキされた素材のリー ドフレーム等から, 金属の剥離溶解, 電解回収を同時に行う。剥 離された母材はメーカーで原料として再使用される。

3・ $2 \cdot 6$ 酸処理工程硝酸で金銀を溶解剥離・濃縮する 工程である。原料はニッケルの多層メッキされた蒸着金銀屑や, フィルム状のもの等である。金銀が高品位であるため, ニッケル を溶解した後の残渣を, 次項目で述べる精金所工程で全量乾式溶 解し, 均一化されたメタルから分析值を確定する。

また, 酸性液やパラジウムを含有した液は, 亜鉛末置換もしく は薬品を用いて金，銀，パラジウムを沈澱物として回収する。

$3 \cdot 2 \cdot 7$ 精金所工程 精金所では, 上記の各工程で得ら れた電解析出物や沈澱物の状態で回収された貴金属を, 重油炉, 精製炉を使用して, 金塊, 銀塊, 青金塊 ( 金と銀の合金)をつくる。 これらは三井金属鉱業(株)竹原製棟所一送り,さらに精製される。

また, 金, 銀, パラジウム含有のウエス, ペースト, 活性炭, レジンなどの原料は，小規模な焙焼装置にて処理する。これらの 原料は, 全量焙焼後の灰を乾式分析して分析值を確定する。

$3 \cdot 2 \cdot 8$ 乾留ガス化炉工程 金, 銀, パラジウム等を含 む基板屑, フィルム屑などの銅屑は, 乾留ガス化炉にて乾留減容 化して有価金属を濃縮し，銅製錬所一送っている。

\section{$3 \cdot 3$ 廃液処理工程 (シアン回収工程 )}

串木野鉱山社における廃液処理工程フローを, Fig. 4 に示す。

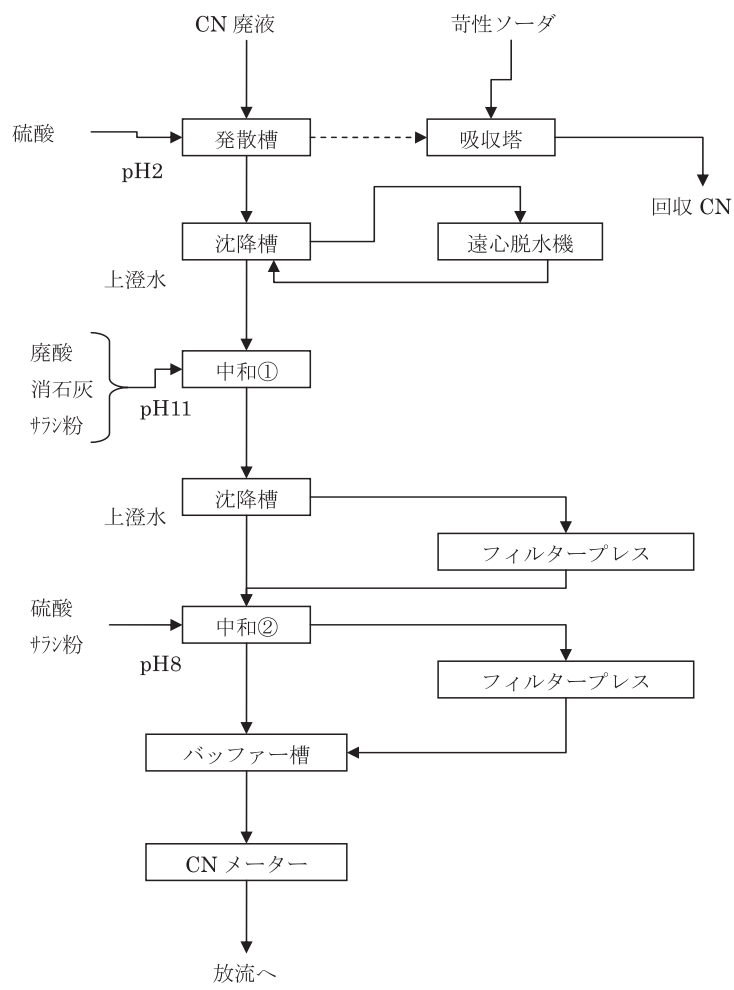

Fig.4 Flow sheet of waste water treatment process.

廃液処理工程では, 青化製棟工程液やリサイクル工程尾液を, 酸添加曝気吸収法と, アルカリ塩素法の併用で処理している。

硫酸添加による酸分解でシアン化水素ガスを発生させ, 苛性 ソーダシャワーで吸収させて回収する。回収したシアンは青化工 程で再利用する。また, リサイクル各工程で発生した酸, アルカ リ廃液は，アルカリ塩素法と同時に中和処理されている。

\section{$3 \cdot 4$ 新しい原料への対応}

当初, リサイクル原料からの貴金属回収は, 処理できる物のみ を青化製棟工程へ投入するというものだった。その後, 原料の形 状, 性状, 品種の多様化に対応して, 専用の処理工程を徐々に整 備して対応してきた。しかし，一部の高品位品を酸処理している 他は，いずれも基本的にシアンの使用とそれを応用する湿式処理 であった。

2005 年 12 月, それまで試験的に処理していた, ITO 含有酸性 液からの In 回収を，新たに工場を設置して本格的に開始した。

串木野鉱山社の親会社である三井金属鉱業 (株) は, 国内主要 ITO ターゲット製造メーカーである。三井金属鉱業 (株) 竹原製 棟所の機能粉工場, 同所金属工場とともに, 串木野鉱山社も ITO ターゲット事業におけるリサイクルスキームの一翼を担っている。

また先ごろ, Pt 含有原料からの Pt 回収工場が稼働を開始した。

このように, 事業環境が好調といわれる中でも, 常に次の柱と なる事業を追い求めてきており, 今後共, 新規原料のリサイクル 技術開発に挑戦し続け,循環型社会形成の一翼を担っていきたい。

\section{References}

1) K.Nakamura: Chishitsu News no.601, pp.30-35, September, 2004

2) H. Miyagawa: Journal of MMIJ, 109(1993), 129-132.

3) A. Hamada: Shigen Shori Gijutsu volume 47 no. 4 extra printing pp.61-65, November, 2000. 4) Y. Urashima: Chishitsu News no.599, pp.20-30, July, 2004.

5) JOGMEC Text: New Technology for Gold Recovery CIP (1995), pp2-4

6) SUMITOMO METAL MINING CO., LTD homepage: http://www.smm.co.jp/metal/ basemmetal.html 